\title{
INVESTIGATION OF THE RELAXATIONS IN THE EXCITED ELECTRONIC STATE OF THE POLYMETHINE DYES IN SOLUTIONS VIA TWO-STEP EXCITED FLUORESCENCE
}

\author{
R. KAARLI, A. REBANE. POLOMETOUNVARVAINETE LAHUSTE ERGASTATUD ELEKTRON \\ SEISUNDIS TOIMUVATE RELAKSATSIOONIPROTSESSIDE UURIMINE \\ KAHEASTMELISELT ERGASTATUD LUMINESTSENTSI ABIL
}

Р. КААРЛИ, А. РЕБАНЕ. ИССЛЕДОВАНИЕ ПРОЦЕССОВ РЕЛАКСАЦИИ В ВОЗБУЖДЕННОМ ЭЛЕКТРОННОМ СОСТОЯНИИ РАСТВОРОВ ПОЛИМЕТИНОВЫХ КРАСИТЕЛЕИ ПРИ ПОМОЩИ ДВУХСТУПЕНЧАТОГО ВОЗБУЖДЕНИЯ ЛЮМИНЕСЦЕНЦИИ

(Presented by K. K. Rebane)

Ultrafast molecular relaxations treated in this short note were experimentally studied via two-step excited fluorescence (TSEF) described in $\left[{ }^{1,2}\right]$. The method lies in exciting dye molecules into first excited electronic state $S_{1}$ by a short optical pulse tracked by a delayed second pulse which further excites the molecules into the next excited state $S_{2}$. Plotting the intensity of the following $S_{2} \rightarrow S_{0}$ fluorescence as a function of delay between the pulses, one can trace the temporal decay of $S_{1}$ state population. If the phase memory of the excited molecules is comparable to pulse duration, $S_{1}$ state phase relaxation can also be studied.

In the experimental set-up a pulse train from a synchronously-pumped mode-locked Oxazine 1 dye laser * (7000-8000 $\AA)$ was devided in a Michelson-type interferometer into two collinear equal intensity beams with variable time delay between the pulses. The beams were focussed to a $100-50 \mu$ spot in a cell filled with $10^{-4}(M / 1)$ dye solution. Quite low excitation power $\left(1 \mu \mathrm{J} / \mathrm{cm}^{2} \mathrm{pp}\right)$ was needed to induce $S_{2}$ fluorescence easily detectable by a conventional photon-counting system. Scattered laser light and $S_{1}$ fluorescence were blocked by a pack of SZS-22 filters. The duration and coherence characteristics of the pulses were varied by using either main tuning wedge or 2-plate birefrigent filter. The pulses obtained by the wedge were $5-6$ ps in duration ** and they revealed, due to incomplete mode-locking a very sharp coherent spike both in autocorrelation and TSEF measurements. Replacing the wedge with the 2-plate birefrigent filter resulted in completely mode-locked $2-5 \mathrm{ps}$ pulses*** with smooth autocorrelation and TSEF traces. To monitor the

* Spectra-Physics Model 375 Dye Laser pumped by acousto-optically mode-locked Spectra-Physics Model 171 Krypton Ion Laser.

*** With low pumping power $1-2$ ps pulses were achieved, in $\left[{ }^{3}\right]$.

*** Results of direct streak camera study of the laser operation are considered 


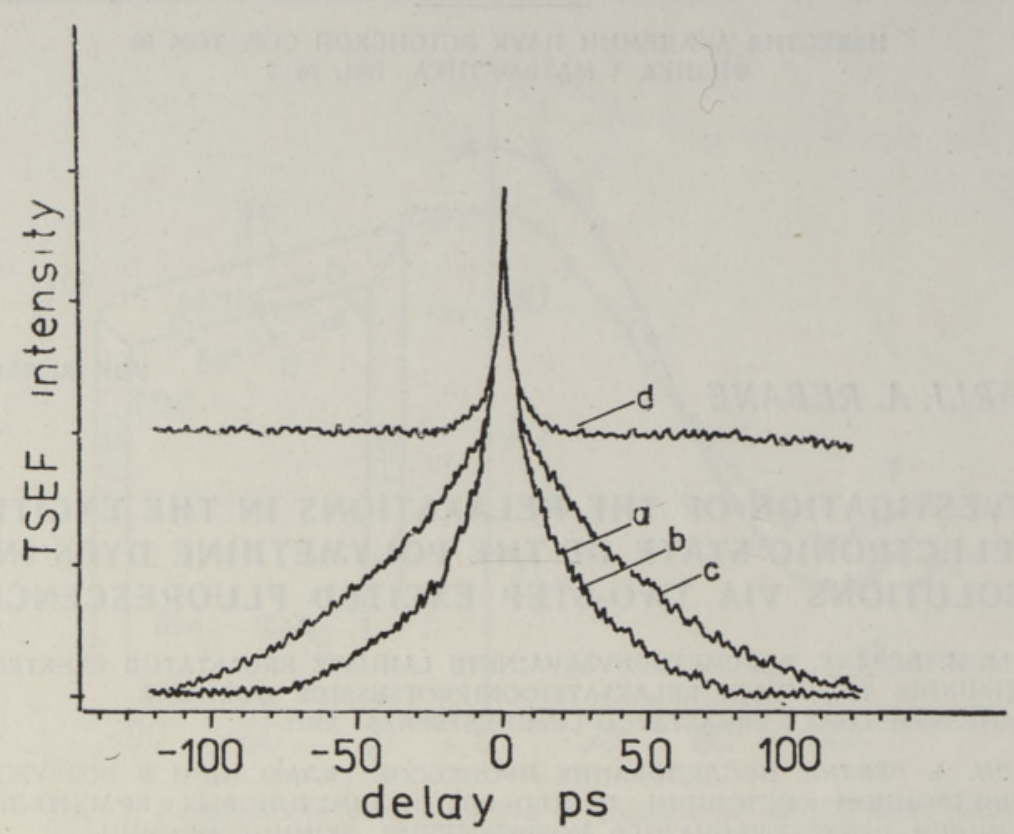

TSEF traces: $a-$ DCI in acetone, $b-$ DDI in ethanol, $c-$ DCI in ethanol, $d-$ a polymethine dye with $T_{1}>500 \mathrm{ps}$.

autocorrelation of the pulses we used a CW $14 \mathrm{~Hz}$ autocorrelator with KDP crystal for noncollinear SHG $\left[{ }^{4}\right]$.

We measured $S_{1}$ state decay time at $300 \mathrm{~K}$ of cryptocyanine (DCI). It was $45+3$ ps in ethanol, and $26+2$ ps in acetone solutions. DDI (1,1-diethyl-2,2-dicarbocyanine iodide) ethanol solution gave also $26 \pm 2 \mathrm{ps}$ decay time (Figure, $b$ ). These results supplement not yet consistent data obtained lip to now in measurements by various techniques $\left[{ }^{5,6}\right]$ including streak camera studies $\left[{ }^{7,8}\right]$.

Cooling DCI solutions to liquid nitrogen temperature revealed a significant prolongation of $S_{1}$ state energy relaxation time which refers to a freezing of vibrational mechanisms responsible for fast nonradiative decay of $S_{1}$ state at room temperature. Further cooling of the samples towards liquid helium temperature $(4.2 \mathrm{~K})$ led to a drastic decrease of $S_{2}$ fluorescence signal probably due to photochemical processes, which result in burning a deep hole in the $S_{1}$ state inhomogeneously broadened absorption spectrum. The study of the luminescence spectra proved that at $4.2 \mathrm{~K}$ monochromatically excited DCI exhibited a structural $S_{1}$ fluorescence spectrum with a number of narrow spectral lines corresponding to no-phonon transitions. The spectral widths of the lines were in good agreement with those of the no-phonon lines in the $\mathrm{DCl}$ excitation spectrum obtained via independent hole-burning experiments. The linewidths of the no-phonon lines in the region $200-300 \mathrm{~cm}^{-1}$ above the $0-0$ transition were about $3 \AA$ at $4.2 \mathrm{~K}$ and they were accompanied by clear phonon sidebands. These results support the assumption that the reason of absence of $S_{2}$ fluorescence at low temperatures lies in the very fast hole burning processes at our excitation intensities and concentrations of dye molecules.

Under certain excitation conditions an anomalous intensity dependence of $S_{2}$ fluorescence signal in the temperature region $30-60 \mathrm{~K}$ was 
observed. We hope to publish more detailed data about these dependences as well as on the spectra elsewhere.

As mentioned above, the coherent coupling at about zero delay between the pump-and-probe pulses gives rise to a coherent spike in TSEF traces much like those obtained in ground state recovery and transient grating measurements $\left[{ }^{9}\right]$. In our case it must be considered that the shape and relative peak intensity of the spike are almost insensitive to $S_{1}$ state energy relaxation time and depend solely on amplitude and phase relations between the two pulses. Without further analysis one can see that in the limit of infinite $S_{1}$ state lifetimes (Figure, $d$ ) the curves obtained from TSEF measurements correspond directly to the internal coherence correlation of laser pulses. This method of the coherence time studies of laser pulses seems both simplier and more precise than those based on detecting light-induced gratings $\left[{ }^{10}\right]$, and it requires merely a dye with suitable spectral characteristics and sufficiently long relaxation times.

In conclusion we must say that TSEF has recommended itself as a simple and precise method for investigating both coherent and incoherent phenomena in ultrafast light and matter interaction providing good time resolution, limited only by pulses autocorrelation. In addition it has an advantage of probing states with very low quantum yield being invisible for streak cameras, and it can also be used in laser technic for the detection of internal coherence characteristics of the ultrashort light pulses when applied under conditions described above.

We would like to thank K. K. Rebane for initiating and stimulating the work. We are grateful to P. Saari for constant support and valuable discussions and to R. Jaaniso for help in hole-burning experiments.

\section{R EFERENCES}

1. Re ntze pis, P. M., Chem. Phys. Lett., 2, № 1, 117-121 (1968).

2. I p pen, E. P., Shank, C. V., Woerner, R. L., Chem. Phys, Lett., 46, № 1, $20-23(1977)$.

3. Аниялг А. О., Берик Е. Б., Вилл А. А., Кукк П. Л., Михкельсоо В. Т., $\mathrm{C}$ a а р и П. М., Ти м п м нн К. Э., Фрей берг А. М., Материалы II советско-французского симпозиума по оптическому приборостроению (в печати).

4. Ka a rli, R., Aaviksoo, J., Freiberg, A., Sa a ri, P., ENSV TA Toimet., Füüs. Matem., 29, № 2, 181-186 (1980).

5. Fouassier, J.-P., Lougnot, D.-J., Faure, J., Chem. Phys. Lett., 30, № 3, $448-450(1975)$.

6. D u g u a y, M. A., H a n s e n, J. W., Opt. Commun., 1, № 5, 254-256 (1969).

7. P a erschke, H., S üsse, K.-E., Welsch, D.-G., Chem. Phys. Lett., 66, № 2, $376-380$ (1979).

8. Tredwell, C. J., Ke a ry, C. M., Chem. Phys., 43, № 1, 307-316 (1979).

9. I p p e n, E. P., Sh a n k, C. V., In: Topics in Applied Physics, 18, Ultrashort Light Pulses, ed. Shapiro S. L., Springer-Verlag, Berlin-Heidelberg-New York, 1977, p. 109 .

10. E ichler, H. J., Kle in, U., L a n ghans, D., Appl. Phys., 21, № 2, 215-219 (1980).

Academy of Sciences of the Estonian SSR, Institute of Physics 